\title{
EVALUATING THE CAPACITY OF HUMAN SERUM ALBUMIN TO REDUCE NON-SPECIFIC BINDING OF MELOXICAM IN THE ULTRAFILTRATION PROCESS
}

\author{
SILVIA IMRE ${ }^{1,2}$, CAMELIA-MARIA TOMA ${ }^{1,2 *}$, CAMIL-EUGEN VARI $^{3}$ \\ ${ }^{I}$ Department of Analytical Chemistry and Drug Analysis, Faculty of Pharmacy, "George Emil Palade” University of Medicine, \\ Pharmacy, Science, and Technology of Târgu Mureș, 38 Gheorghe Marinescu Street, RO-540142, Târgu Mureș, Romania \\ ${ }^{2}$ Center of Advanced Medical and Pharmaceutical Research, "George Emil Palade" University of Medicine, Pharmacy, \\ Science, and Technology of Târgu Mureș, 38 Gheorghe Marinescu Street, RO-540142, Târgu Mureș, Romania \\ ${ }^{3}$ Department of Pharmacology and Clinical Pharmacy, Faculty of Pharmacy, "George Emil Palade" University of Medicine, \\ Pharmacy, Science, and Technology of Târgu Mureș, 38 Gheorghe Marinescu Street, RO-540142, Târgu Mureș, Romania
}

*corresponding author: camelia.toma@umfst.ro

Manuscript received: August 2021

\begin{abstract}
Due to the importance that plasma protein binding of drugs plays and the constant interest to optimize study methods of the process, this study aimed to test the capacity of a human serum albumin solution to reduce non-specific binding of highly bound meloxicam, based on the ability of the protein to block most non-specific binding sites of the ultrafiltration devices. Samples of meloxicam and internal standard piroxicam were prepared in both phosphate-buffered saline solution, commonly used in biological research, and 5\% human serum albumin solution. After the ultrafiltration process, the free drug fraction was analysed using a reversed phase HPLC-UV method. A decrease in the concentration of meloxicam after ultrafiltration in both matrices was observed, the decrease being higher in the case of phosphate-buffered saline solution. The mean determined degree of binding to albumin for meloxicam was 55\%. The high decrease in concentration for meloxicam in the non-proteic matrix indicates a very high degree of non-specific binding, phenomenon which appears to be indeed reduced for the samples prepared in human serum albumin solution. The study also emphasises the very close attention that should be paid to the preparation and processing of samples in protein matrices and to the experimental conditions.
\end{abstract}

\section{Rezumat}

Datorită importanței pe care legarea medicamentelor de proteinele plasmatice o prezintă și a interesului constant de a optimiza metodele de studiu ale procesului, acest studiu a avut ca scop testarea capacității unei soluții de albumină serică umană de a reduce legarea nespecifică a meloxicamului puternic legat, pe baza capacității proteinei de a bloca majoritatea situsurilor de legare nespecifică a dispozitivelor de ultrafiltrare. Probele de meloxicam şi standard intern piroxicam au fost preparate atât în soluție de tampon fosfat salin, utilizată în mod obişnuit în cercetări biologice, cât și în soluție de albumină serică umană 5\%. După procesul de ultrafiltrare, fracția de medicament liber a fost analizată folosind o metodă HPLC-UV în fază inversă. S-a observat o scădere a concentrației de meloxicam după ultrafiltrare în ambele matrici, scăderea fiind mai mare în cazul soluției de tampon fosfat salin. Gradul mediu de legare de albumină determinat pentru meloxicam a fost de $55 \%$. Scăderea ridicată a concentrației de meloxicam în matricea non-proteică indică un grad foarte ridicat de legare nespecifică, fenomen care pare a fi într-adevăr redus pentru probele preparate în soluție de albumină serică umană. Studiul scoate în evidență, de asemenea, atenția mare care trebuie acordată condițiilor experimentale, preparării și prelucrării probelor în matrici proteice.

Keywords: ultrafiltration, non-specific binding, albumin, meloxicam, protein binding

\section{Introduction}

Plasma protein binding (PPB) has a critical impact on the pharmacokinetic and pharmacodynamic properties of substances, influencing also their toxicity, which may increase as a result of displacement interactions $[2,3,7,12,22,33,37]$.

In general, PPB is a reversible phenomenon, being governed by the law of mass action, which ultimately leads to a balance between the bound and free drug fractions. It is commonly accepted that in the absence of a specific transport system, only free drug molecules are able to diffuse through membranes and can be distributed to the tissues leading to a pharmacological effect [2, 7, 12, 23, 37]. Regarding the binding of exogenous compounds, the most important plasma proteins involved in the process are human serum albumin (HSA) and alpha-1-acid glycoprotein (AGP), followed by lipoproteins and globulins. HSA has an extraordinary capacity to reversibly bind ligands that are mainly acidic, but also neutral $[9,15]$. HSA has multiple binding sites, but, among these, only two are specific for exogenous substances. These are known as the Sudlow I and Sudlow II site or the warfarin site 
(site I) and the benzodiazepine site (site II), depending on the substances for which they are specific $[2,9$, $12,15,36]$. A third site for which the existence of a specificity for digitoxin binding was demonstrated, is mentioned in the literature, but it has been studied in a lower manner [6, 28, 39]. AGP is an acute phase protein with a lower binding capacity than albumin, but a higher affinity for ligands, which makes the dissociation of the bound drug molecules more difficult. Although it has a very high affinity for basic substances, some neutral or acidic compounds and endogenous steroid hormones such as progesterone, can also bind to it. Multiple binding sites have been reported in the case of AGP, but only one of them has been shown to be important for the process of drug binding [10, 12, 15].

Regarding the study of PPB, various methods were developed and described in the literature, but from the perspective of drug development, only equilibrium dialysis and ultrafiltration (UF) are widely accepted $[3,5,12,15,20,33,34,37,38]$.

UF uses a semipermeable membrane for the physical separation of bound and free drug fractions, and it is considered to be one of the fastest and simplest methods for determining the free fraction of a drug which could also be used during clinical monitoring $[3,12,20,30,38]$.

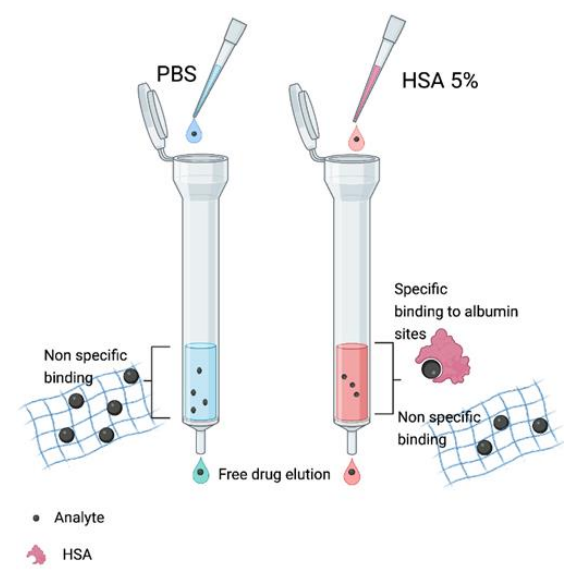

Figure 1.

Experimental in vitro protocol in order to asses NSB (created with BioRender.com)

The highest disadvantage of the UF method, however, is the non-specific binding (NSB) of substances to the semi-permeable membrane and to the compartment of the UF device, which provide NSB sites due to their characteristic polarity and charge $[3,12,16,20$, $30,35,38]$. There is a constant interest regarding the optimization of the UF method in order to overcome this limitation [1, 8, 11, 13, 16, 17, 29, 30, 35]. In a study by Wang $\mathrm{C}$ and Williams NS [35], which had a mass balance approach, it was observed that the behaviour of some compounds in terms of NSB is very different when they are incubated with the UF device in plasma compared to phosphate buffered saline (PBS), commonly used in biological research (Figure 1). This was thought to be a consequence of the fact that serum proteins can adsorb on the surface of different types of materials, leading to the blockage of most NSB sites. The study showed that, using this approach, the limitation given by NSB can be overcome even in the case of compounds with increased lipophilia.

In the present study, we aimed to assess whether a human serum albumin solution has the capacity to reduce NSB using meloxicam (MXC) and piroxicam (PXC) as reference substances. MXC and PXC are both non-steroidal anti-inflammatory drugs [25, 26] that have a high affinity for plasma proteins, especially albumin $[4,18,19,27,31]$. The interaction between meloxicam and HSA is strong in nature, occurring at a single site with high affinity, which is found in the IIA sub-domain and has an association constant of the order of $10^{5} \mathrm{M}^{-1}$ [27, 31, 32]. Meloxicam is bound to human serum albumin mainly by hydrophobic interactions, but hydrogen bonds cannot be excluded either. In the case of piroxicam, studies have shown that it binds to albumin in the IIA subdomain, where tryptophan and tyrosine residues are present, but in addition to this, it may also bind to tyrosine residues located in the IB, IIB or IIIA subdomains [19, 24]. Binding of piroxicam to human serum albumin is a spontaneous and exothermic process involving the presence of hydrogen bonds and hydrophobic interactions. The association constant is also of the order of $10^{5} \mathrm{M}^{-1}[4$, 21]. The choice of MXC - PXC combination was made based on the fact that often the two substances are used in tandem analyte - internal standard for quantification from biological samples using chromatographic techniques [14]. In the present study, piroxicam was used as an internal standard (ISTD).

\section{Materials and Methods}

Reference substances, reagents and solvents The substances were obtained as follows: MXC (working standard) was obtained from a local pharmaceutical company, while PXC (working standard) was obtained from Nantong Jinghua Pharmaceuticals Co LTD (China). Acetonitrile, methanol, phosphoric acid $85 \%$, sodium chloride, potassium chloride, disodium phosphate, potassium dihydrogen phosphate were purchased from Merck (Germany), hydrochloric acid $32 \%$ was purchased from Micromchim (Romania) and sodium hydroxide from Chemapol (Czech Republic), all of the reagents had appropriate analytical purity. Human Albumin Grifols 200 g/L, solution for infusion, was purchased from Instituto Grifols SA (Spain).

Chromatographic conditions

The conditions for the chromatographic analysis were established after a slight modification of a previously 
published method by Imre $\mathrm{S}$ et al. [14]: the same HPLC system Agilent Technologies 1100 Series type was used and the analytical column was Zorbax SBC18 (Solvent Saver Plus 100 x 3 mm, $3.5 \mu \mathrm{m}$ ). The column temperature was set at $45^{\circ} \mathrm{C}$. The mobile phase contained a mixture of acetonitrile (ACN) and $15 \mathrm{mM}$ phosphoric acid $\left(\mathrm{H}_{3} \mathrm{PO}_{4}\right)$ solution, according to the following gradient: 0 - $1 \mathrm{~min}$ isocratic elution $77 \%$ $\mathrm{H}_{3} \mathrm{PO}_{4} 15 \mathrm{mM}, 23 \%$ ACN; 1 - 6 min gradient elution $77 \% \rightarrow 60 \% \mathrm{H}_{3} \mathrm{PO}_{4} 15 \mathrm{mM}, 23 \% \rightarrow 40 \% \mathrm{ACN} ; 6-7$ min restoring the initial composition $60 \% \rightarrow 77 \%$ $\mathrm{H}_{3} \mathrm{PO}_{4} 15 \mathrm{mM}, 40 \% \rightarrow 23 \%$ ACN; 7 - 10 min reequilibration step $77 \% \mathrm{H}_{3} \mathrm{PO}_{4} 15 \mathrm{mM}, 23 \% \mathrm{ACN}$. The flow rate was $1.7 \mathrm{~mL} / \mathrm{min}$, sample temperature $20^{\circ} \mathrm{C}$ and the injection volume $40 \mu \mathrm{L}$. The detection wavelength was set at $364 \mathrm{~nm}$.

Preparation of stock and standard solutions Stock solution of MXC and PXC. The final stock solutions of MXC and PXC with a concentration of 6 $\mu \mathrm{g} / \mathrm{mL}$ were prepared by the corresponding dilution with PBS (pH 7.40) of an initial solution, with a concentration of $300 \mu \mathrm{g} / \mathrm{mL}$ prepared in methanol. The concentration of methanol in the final stock solutions was $2 \%(\mathrm{v} / \mathrm{v})$.

Standard solutions. Seven calibration standards with increasing concentrations of MXC $(15,30,150,900$, $1500,2100,2400 \mathrm{ng} / \mathrm{mL}$ ) and a constant concentration of PXC as an ISTD $(600 \mathrm{ng} / \mathrm{mL})$ were prepared by dilution of the final stock solutions with PBS (pH 7.40) and 5\% HSA solution, respectively. The 5\% HSA solution was prepared by the corresponding dilution of the $20 \%$ infusion solution with purified water.

Standard solutions for testing method accuracy and precision and for the UF study. Three levels of standard solutions were prepared in PBS (pH 7.40) and 5\% HSA solution with the concentrations for MXC of 900, 1500 and $2400 \mathrm{ng} / \mathrm{mL}$, respectively, and PXC as an ISTD at a concentration of $600 \mathrm{ng} / \mathrm{mL}$.

Experimental UF protocol

Amicon Ultra-2 centrifugal filter units (Ultracel-10K regenerated cellulose membrane, $2 \mathrm{~mL}$ ) were purchased from Merck (Germany). The ultrafiltration tubes were weighted before and after the UF process. UF of $1000 \mu \mathrm{L}$ samples was performed at room temperature, applying a relative centrifugal force (RCF) of $5000 \mathrm{~g}$, for 10 minutes. Two series of MXC and PXC solutions prepared in PBS and 5\% HSA solution, respectively, were subjected to parallel UF. The three concentration levels chosen for MXC correspond in order of magnitude to the plasma levels achieved after administration of a single dose of $20 \mathrm{mg}$ MXC: 900,1500 and $2400 \mathrm{ng} / \mathrm{mL}$. The concentration of PXC in the analysed samples was $600 \mathrm{ng} / \mathrm{mL}$.

Processing of samples and standard solutions for HPLC analysis

For the HPLC analysis, the samples and standard solutions prepared in 5\% HSA were subjected to precipitation with a solution of $20 \%$ perchloric acid $\left(\mathrm{HClO}_{4}\right)$, the ratio of $5 \% \mathrm{HSA}$ solution: $\mathrm{HClO}_{4} 20 \%$ being 20:3. After the addition of $\mathrm{HClO}_{4} 20 \%$, the solutions were vortexed for one minute, left at rest for 5 minutes and centrifuged for 10 minutes at $10000 \mathrm{rpm}$, after which the supernatant was subjected to analysis. The same treatment was applied to the samples in 5\% HSA solution both before and after UF, but also to the samples and standard solutions prepared in PBS.

\section{Results and Discussion}

Quality parameters of the applied analytical method The experimental analytical approach was based on the modification of an HPLC method with UV detection previously developed and validated by Imre $\mathrm{S}$ et al. [14]. A column with the same geometric characteristics and particle size was used, but with C18 stationary phase, instead of $\mathrm{C} 8$, and a $15 \mathrm{mM}$ phosphoric acid solution for the mobile phase, instead of phosphate buffer. Taking into account the fact that the difference in stationary phase is only in terms of hydrophobicity and the $\mathrm{pH}$ difference of the aqueous mobile phase is in a domain in which MXC and PXC are in the same ionization form, as acid $\left(\mathrm{pK}_{\mathrm{aMXC}}=4.2 ; \mathrm{pK}_{\mathrm{aPXC}}=5.5\right)$, and the same equipment was used, it was considered that the modified method can be applied in the present study verifying its analytical performance in terms of specificity, linearity, accuracy and precision. All these parameters proved to be appropriate as it follows.

Specificity. MXC and PXC (ISTD) are specifically separated at retention times of $5.199( \pm 0.073) \mathrm{min}$ and $2.755( \pm 0.105) \mathrm{min}$, respectively, in both PBS $(\mathrm{pH} 7.4)$ and 5\% HSA solution.

Linearity. The calibration equation in PBS was Area ratio $=0.0018 c+0.0141(\mathrm{~N}=7)$ and the correlation coefficient was $r>0.999$. The residuals showed a random variation, being below $4 \%$ in absolute values. In the case of standard solutions in 5\% HSA, the calibration equation was Area ratio $=0.00111 \mathrm{c}$ 0.15442 with a correlation coefficient $r>0.998$ over $900-2400 \mathrm{ng} / \mathrm{mL}$ concentration range, a relevant biological concentration domain. The residuals, as well, showed a random variation, being below $4 \%$ in absolute values.

Accuracy and precision. The relative standard deviation DSR\% and the relative error Er\% for intra-series $(\mathrm{n}=3)$ precision and accuracy of the method had absolute values below $2 \%$ for determinations made in PBS, suitable for analytical determinations, and below $10 \%$, for those in 5\% HSA, adequate for bioanalytical determinations.

Relative recovery of the analyte. The mean relative recovery of MXC was $98.38 \%( \pm 4.30)$.

Qualitative study of the non-specific binding of MXC and PXC to the ultrafiltration device used

Taking into account data from the literature on the NSB of substances to the ultrafiltration device materials, 
as well as indicated methods that could reduce this phenomenon, it was studied whether a human serum albumin solution would resolve possible NSB of meloxicam and piroxicam compared to PBS. As suggested and demonstrated by Wang $\mathrm{C}$ and Williams NS [35] serum proteins can adsorb on the surface of different types of materials, leading to the blockage of most NSB sites. The device used in the present study was made of styrene-butadiene copolymer with a filter membrane of regenerated cellulose.

Figures 2 and 3 show comparative chromatograms of a $2400 \mathrm{ng} / \mathrm{mL}$ MXC sample before and after UF in PBS and 5\% HSA solution, respectively.

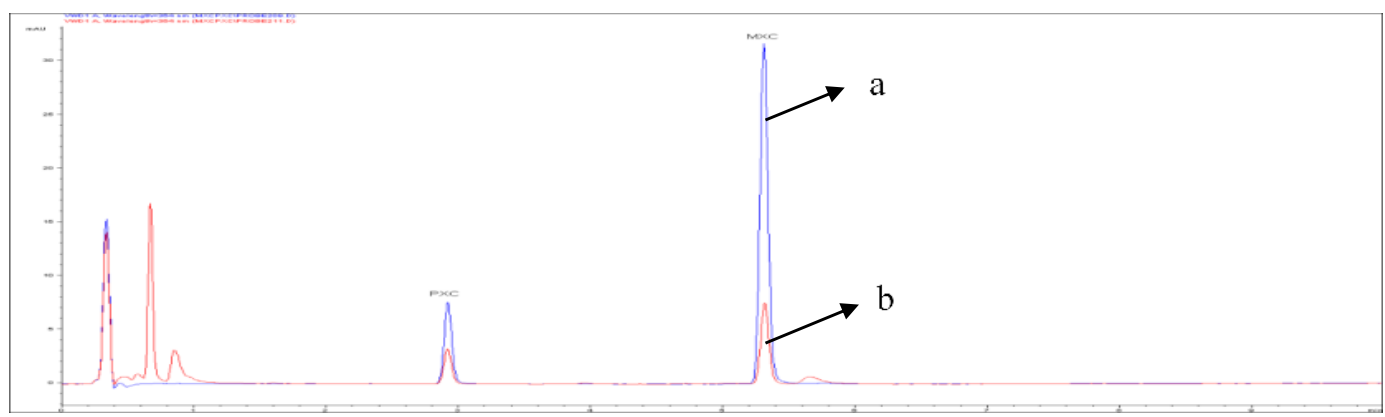

Figure 2.

Chromatograms of a $2400 \mathrm{ng} / \mathrm{mL}$ MXC sample (PXC $600 \mathrm{ng} / \mathrm{mL}$ ) in: a) PBS, b) 5\% HSA, before UF

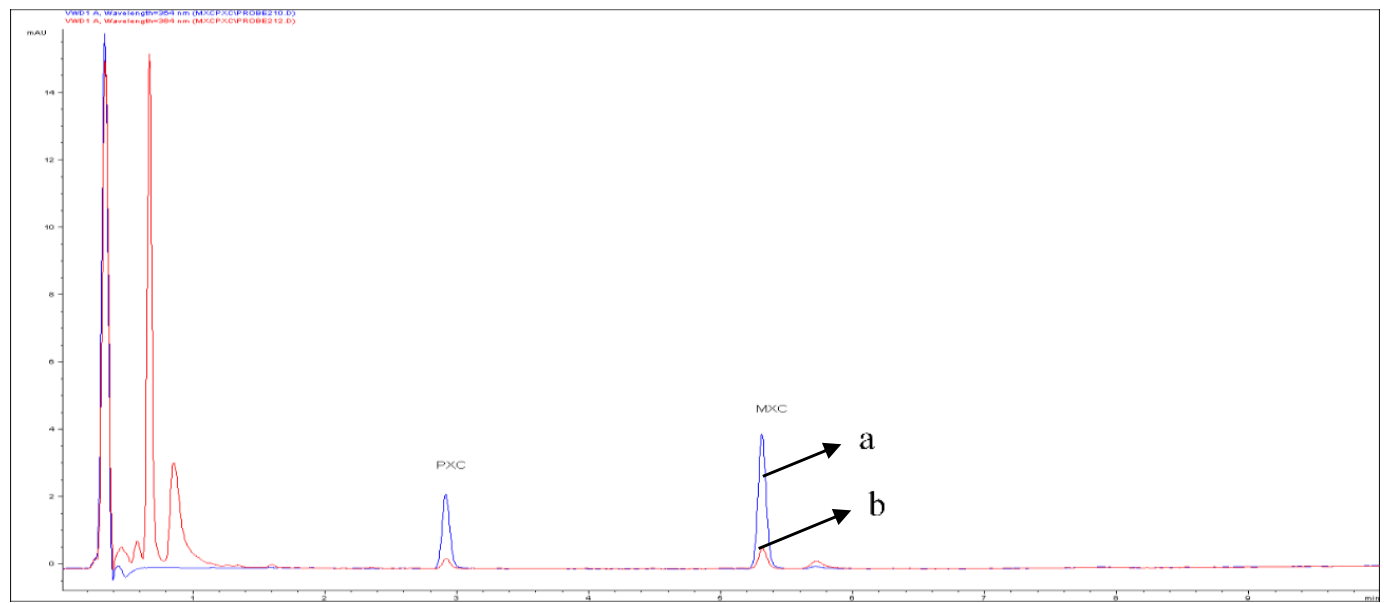

Figure 3.

Chromatograms of a $2400 \mathrm{ng} / \mathrm{mL}$ MXC sample (PXC $600 \mathrm{ng} / \mathrm{mL}$ ) in: a) PBS, b) 5\% HSA, after UF

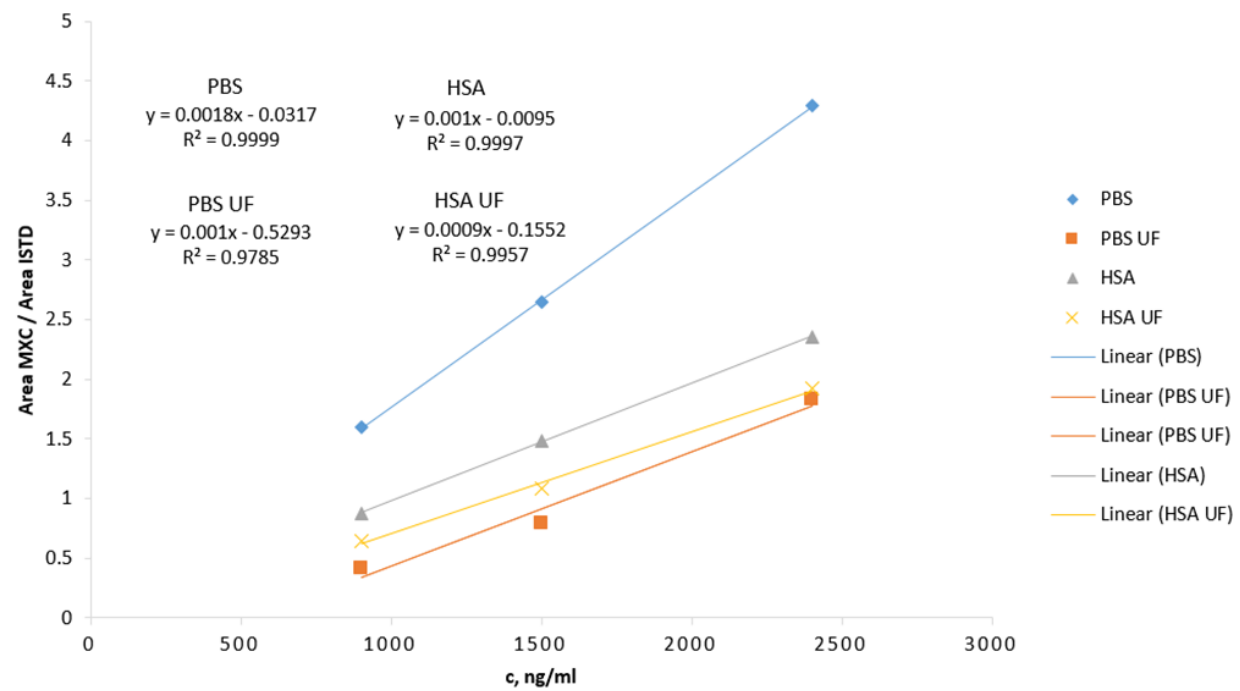

Figure 4.

Correlation of MXC/PXC area ratio with theoretical concentration level for MXC samples prepared in PBS and $5 \%$ HSA, before and after UF 
Assay of MXC and PXC samples in the two matrices considered, before and after UF

\begin{tabular}{|c|c|c|c|c|c|c|}
\hline \multirow{2}{*}{ Before/After UF } & \multirow{2}{*}{ Matrix } & \multicolumn{2}{|c|}{ MXC } & \multicolumn{2}{|c|}{ PXC } & \multirow{2}{*}{$\begin{array}{l}\text { Area ratio } \\
\text { MXC/PXC }\end{array}$} \\
\hline & & $\mathrm{C}(\mathrm{ng} / \mathrm{mL})$ & Area & $\mathrm{C}(\mathrm{ng} / \mathrm{mL})$ & Area & \\
\hline Before UF & \multirow{2}{*}{ PBS } & \multirow{4}{*}{900} & 51.1 & \multirow{12}{*}{600} & 32 & 1.597 \\
\hline After UF & & & 2.3 & & 5.6 & 0.411 \\
\hline Before UF & \multirow{2}{*}{ HSA } & & 11.4 & & 13.1 & 0.870 \\
\hline After UF & & & 0.84 & & 1.3 & 0.646 \\
\hline Before UF & \multirow{2}{*}{ PBS } & \multirow{4}{*}{1500} & 85.5 & & 32.3 & 2.647 \\
\hline After UF & & & 5.3 & & 6.7 & 0.791 \\
\hline Before UF & \multirow{2}{*}{ HSA } & & 19.9 & & 13.4 & 1.485 \\
\hline After UF & & & 1.3 & & 1.2 & 1.083 \\
\hline Before UF & \multirow{2}{*}{ PBS } & \multirow{4}{*}{2400} & 137.7 & & 32.1 & 4.290 \\
\hline After UF & & & 17.2 & & 9.4 & 1.830 \\
\hline Before UF & \multirow{2}{*}{ HSA } & & 32.7 & & 13.9 & 2.353 \\
\hline After UF & & & 2.5 & & 1.3 & 1.923 \\
\hline
\end{tabular}

The aim of the study was to provide an estimation of the behavior of MXC and PXC regarding both nonspecific and HSA binding, thus singlicate measurements were used.

From the data collected after the experimental assay, several qualitative interpretations can be made: there is a decrease in concentration for MXC and PXC after UF compared to the initial solution, both in PBS and HSA solution (Figures 2 and 3); the decrease in concentration is much more pronounced in the case of PBS solutions compared to HSA, which indicates that indeed HSA blocks NSB sites to some extent. Even in terms of area ratio, there is a decrease after UF, which indicates a different behaviour of the two substances both in terms of NSB, but also in terms of binding to albumin (Table I). The assignment of a linear mathematical model to the experimental points shown in Figure 4 indicates a very good

correlation in the case of solutions prepared in PBS and HSA before UF but it is observed that after UF, the linearity is somewhat reduced for the solutions prepared in HSA and is no longer appropriate in the case of PBS (correlation coefficient < 0.99). Therefore, the PBS solution, at least in the case of the substances considered, appears to be an unfavourable factor in terms of NSB compared to albumin. Albumin acts favourably from this point of view, probably blocking at least some of the binding sites, thus diminishing the NSB.

Determination of the degree of binding of MXC to human serum albumin under the tested experimental conditions

Under the experimental conditions of the study, we assessed a reproducible degree of binding of MXC to HSA of about 55\% (Table II), determined in singlicate at three levels of concentration.

Table II

Recovery of MXC after UF in 5\% HSA solution

\begin{tabular}{|c|c|c|c|c|c|c|}
\hline Before/After UF & $\mathrm{C}(\mathrm{ng} / \mathrm{mL})$ & $\mathbf{m}_{\text {sol }}, \mathbf{g}$ & $\mathrm{m}_{\mathrm{MXC}}, \mathrm{ng}$ & Recovery \% & Mean Recovery \% (DSR\%) & Degree of binding \\
\hline Before UF & 923.1 & 0.9922 & 915.9 & \multirow{2}{*}{44.13} & \multirow{6}{*}{$45.16(6.98)$} & \multirow{6}{*}{54.84} \\
\hline After UF & 721.2 & 0.5605 & 404.2 & & & \\
\hline Before UF & 1477 & 0.9958 & 1470.8 & \multirow{2}{*}{42.64} & & \\
\hline After UF & 1115.1 & 0.5625 & 627.2 & & & \\
\hline Before UF & 2258.5 & 0.9883 & 2232 & \multirow{2}{*}{48.69} & & \\
\hline After UF & 1871.6 & 0.5807 & 1086.8 & & & \\
\hline
\end{tabular}

The determined binding degree of MXC to HSA is well below the value of over $99 \%$ reported in the literature [27, 31]. Possible explanations for this result: it was used standardized HSA solution, a much simplified matrix compared to real human plasma; the presence of other compounds in the HSA infusion solution used as a dissolution medium (sodium caprylate, sodium $\mathrm{N}$-acetyltryptophanate) could have influence on the binding of the drugs to HSA; the experiment was performed entirely at room temperature; the relative centrifugal force was increased during the preliminary tests to $5000 \mathrm{~g}$ from $1000 \mathrm{~g}$, used in other studies in the literature, because filtration was not possible at lower speeds for the considered device, which could have affected the binding equilibrium. However, the DSR\% of 6.98 reveals a reproducible protein binding over a relatively wide concentration domain.

The results of the present study are related to the following issues. There are many physicochemical methods used in laboratory practice that limit NSB (change in $\mathrm{pH}$, electrolyte concentration, co-use of additional compounds - proteins, non-ionic surfactants) [30]. These methods can only be limitedly used in biological matrices without affecting the real characteristics of living systems (for example, biological constants of plasma: $\mathrm{pH}=7.4$, osmotic colloid pressure, type and concentration of electrolytes). On the other hand, 
the use of in vitro experimental models can provide extremely useful information, but these models are based on a rather crude approximation of biological reality (as in this case, the use of a 5\% HSA solution). Useful experiments can be performed using ex vivo models, in which whole blood is processed by centrifugation containing the previously administered analyte (by oral or parenteral route). However, the treatment of the sample can add important differences: the plasma obtained contains many proteins, including 55 to $60 \%$ albumin, but also globulins around $40 \%$, as well as lipoproteins, enzymes, coagulation factors etc. If serum (obtained by centrifugation after blood coagulation) is used, the composition of the biological matrix will be different from plasma in the absence of fibrinogen and most of the coagulation factors. In addition, in the case of the use of whole blood, the binding of some analytes to the blood cells (such as erythrocyte membrane) may occur.

The more complicated the biological model used is, the closer is to the biological reality of the living organism, but the variables are more difficult to control, especially in the case of equilibrium systems, such as binding to plasma proteins.

\section{Conclusions}

In conclusion, it has been observed that non-specific binding is reduced when the samples under analysis are prepared in a protein matrix (human serum albumin in this case), compared to phosphate-buffered saline solution commonly used in biological research. The better results obtained in other studies in which plasma samples were analysed are due to its complex matrix which, in addition to albumin, also contains a number of other proteins, which in turn have the ability to further limit non-specific binding. The present study allows to draw, also, the following conclusions important in protein binding studies: greater attention must be paid to the processing and preparation of samples in protein matrices and to the experimental conditions, in particular temperature and $\mathrm{pH}$, which must correspond to the physiological conditions in order to obtain results with biological relevance; the differences in $\mathrm{pH}$, temperature, matrix composition, in obtaining standard solutions and protocols which do not ensure that the binding equilibrium is reached, especially in the case of substances with a high degree of binding, may greatly influence the experimental results. However, the in vitro protein binding studies by using simplified matrices represent an important step in new drug candidates' characterisation.

\section{Conflict of interest}

The authors declare no conflict of interest.

\section{References}

1. Arellano C, Gandia P, Lafont T, Jongejan R, Chatelut $\mathrm{E}$, Determination of unbound fraction of imatinib and N-desmethyl imatinib, validation of an UPLCMS/MS assay and ultrafiltration method. J Chromatogr B Analyt Technol Biomed Life Sci., 2012; 907: 94-100.

2. Ascenzi P, Fanali G, Fasano M, Pallonttini V, Clinical relevance of drug binding to plasma proteins. $\mathrm{J} \mathrm{Mol}$ Struct., 2014; 1077: 4-13.

3. Bohnert T, Gan LS, Plasma protein binding: from discovery to development. J Pharm Sci., 2013; 102(9): 2953-2994.

4. Brée F, Urien S, Nguyen P, Riant P, Albengres E, Tillement JP, A re-evaluation of the HSA-piroxicam interaction. Eur J Drug Metab Pharmacokinet., 1990; 15(4): 303-307.

5. Chuang VT, Maruyama T, Otagiri M, Updates on contemporary protein binding techniques. Drug Metab Pharmacokinet., 2009; 24(4): 358-364.

6. Curry S, Lessons from the crystallographic analysis of small molecule binding to human serum albumin, Drug Metab Pharmacokinet., 2009, 24(4): 342-357.

7. Deb PK, Al-Attraqchi O, Prasad MR, Tekade RK, Chapter 11 - Protein and tissue binding: implication on pharmacokinetic parameters. In Advances in pharmaceutical product development and research, Dosage form design considerations, Tekade RK Ed., Academic Press, 2018; Volume I: 371-399.

8. Delgado-Magnero KH, Valiente PA, Ruiz-Peña M, Pérez-Gramatges A, Pons T, Unraveling the binding mechanism of polyoxyethylene sorbitan esters with bovine serum albumin: a novel theoretical model based on molecular dynamic simulations. Colloids Surf B Biointerfaces, 2014; 116: 720-726.

9. Fanali G, di Masi A, Trezza V, Marino M, Fasano M, Ascenzi P, Human serum albumin: from bench to bedside. Mol Aspects Med., 2012; 33(3): 209-290.

10. Fournier T, Medjoubi-N N, Porquet D, Alpha-1acid glycoprotein. Biochim Biophys Acta., 2000; 1482(1-2): 157-171.

11. Hoffmann C, Blume A, Miller I, Garidel P, Insights into protein-polysorbate interactions analysed by means of isothermal titration and differential scanning calorimetry. Eur Biophys J., 2009; 38(5): 557-568.

12. Howard ML, Hill JJ, Galluppi GR, McLean MA, Plasma protein binding in drug discovery and development. Comb Chem High Throughput Screen, 2010; 13(2): 170-187.

13. Illamola SM, Labat L, Benaboud S, Tubiana R, Warszawski J, Tréluyer JM, Hirt D, Determination of total and unbound concentrations of lopinavir in plasma using liquid chromatography-tandem mass spectrometry and ultrafiltration methods. J Chromatogr B Analyt Technol Biomed Life Sci., 2014; 965: 216-223.

14. Imre S, Tero-Vescan A, Dogaru MT, Kelemen L, Muntean DL, Curticapean A, Szegedi N, Vari CE, With or without internal standard in HPLC bioanalysis. A case study. J Chromatogr Sci., 2019; 57(3): 243-248.

15. Lambrindis G, Vallianatou T, Tsantili-Kakoulidou $\mathrm{A}$, In vitro, in silico and integrated strategies for the estimation of plasma protein binding. A review. Adv Drug Deliv Rev., 2015; 86: 27-45. 
FARMACIA, 2021, Vol. 69, 6

16. Lee KJ, Mower $\mathrm{R}$, Hollenbeck $\mathrm{T}$, Castelo $\mathrm{J}$, Johnson N, Gordon P, Sinko PJ, Holme K, Lee YH, Modulation of nonspecific binding in ultrafiltration protein binding studies. Pharm Res., 2003; 20(7): 1015-1021.

17. Loos WJ, Baker SD, Verweij J, Boonstra JG, Sparreboom A, Clinical pharmacokinetics of unbound docetaxel: role of polysorbate 80 and serum proteins. Clin Pharmacol Ther., 2003; 74(4): 364-371.

18. Luger P, Daneck K, Engel W, Trummlitz G, Wagner $\mathrm{K}$, Structure and physicochemical properties of meloxicam, a new NSAID. Eur J Pharm Sci., 1996; 4(3): 175-187.

19. McCallum MM, Pawlak AJ, Shadrick WR, Simeonov A, Jadhav A, Yasgar A, Maloney DJ, Arnold LA, A fluorescence-based high throughput assay for the determination of small molecule-human serum albumin protein binding. Anal Bioanal Chem., 2014; 406(7): 1867-1875.

20. Nilsson LB, The bioanalytical challenge of determining unbound concentration and protein binding for drugs. Bioanalysis, 2013; 5(24): 3033-3050.

21. Oyekan AO, Thomas WO, The energetics of the interaction of piroxicam with plasma albumin. J Pharm Pharmacol., 1984; 36(12): 831-834.

22. Palleria $\mathrm{C}$, Di Paolo A, Giofrè $\mathrm{C}$, Caglioti $\mathrm{C}$, Leuzzi G, Siniscalchi A, De Sarro G, Gallelli L, Pharmacokinetic drug-drug interaction and their implication in clinical management. J Res Med Sci., 2013; 18(7): 601-610.

23. Pellegatti M, Pagliarusco S, Solazzo L, Colato D, Plasma protein binding and blood-free concentrations: which studies are needed to develop a drug?. Expert Opin Drug Metab Toxicol., 2011; 7(8): 1009-1020.

24. Równicka-Zubik J, Sułkowski L, Maciążek-Jurczyk M, Sułkowskaa A, The effect of structural alterations of three mammalian serum albumins on their binding properties. J Mol Struct., 2013; 1044: 152-159.

25. Rus LM, Iurian S, Kacsó I, Borodi G, Porav S, Heghes SC, Iuga CA, Tomuță I, Development of meloxicam oral lyophilisates: role of thermal analysis and complementary techniques. Farmacia, 2019; 67(1): 56-67.

26. Rusu A, Ciurba A, Bîrsan M, Antonoaea P, Székely-Szentmiklósi B, Fülöp I Pascu GA, Todoran N, Compatibility study of four binary combinations of active ingredients for dermal film forming systems. Farmacia, 2020; 68(5): 800-811.

27. Seedher N, Bhatia S, Mechanism of interaction of the non-steroidal antiinflammatory drugs meloxicam and nimesulide with serum albumin. $J$ Pharm Biomed Anal., 2005; 39(1-2): 257-262.
28. Sjöholm I, Ekman B, Kober A, Ljungstedt-Påhlman I, Seiving B, Sjödin T, Binding of drugs to human serum albumin:XI. The specificity of three binding sites as studied with albumin immobilized in microparticles. Mol Pharmacol., 1979; 16(3): 767-777.

29. Taylor S, Harker A, Modification of the ultrafiltration technique to overcome solubility and non-specific binding challenges associated with the measurement of plasma protein binding of corticosteroids. $J$ Pharm Biomed Anal., 2006; 41(1): 299-303.

30. Toma CM, Imre S, Vari CE, Muntean DL, TeroVescan A, Ultrafiltration method for plasma protein binding studies and its limitations. Processes, 2021; 9(2): 382: 1-7

31. Trynda-Lemiesz L, Wiglusz K, Interactions of human serum albumin with meloxicam: characterization of binding site. J Pharm Biomed Anal., 2010; 52(2): 300-304.

32. Trynda-Lemiesz L, Wiglusz K, Effects of glycation on meloxicam binding to human serum albumin. $J$ Mol Struct., 2011; 995(1): 35-40.

33. Vuignier K, Schappler J, Veuthey JL, Carrupt PA, Martel S, Drug-protein binding: a critical review of analytical tools. Anal Bioanal Chem., 2010; 398(1): 53-66.

34. Vuignier K, Veuthey JL, Carrupt PA, Schappler J, Global analytical strategy to measure drug-plasma protein interactions: from high-throughput to in-depth analysis. Drug Discov Today, 2013; 18(21-22): 1030-1034.

35. Wang C, Williams NS, A mass balance approach for calculation of recovery and binding enables the use of ultrafiltration as a rapid method for measurement of plasma protein binding for even highly lipophilic compounds. J Pharm Biomed Anal., 2013; 75: 112-117.

36. Yamasaki K, Chuang VT, Maruyama T, Otagiri M, Albumin-drug interaction and its clinical implication. Biochim Biophys Acta., 2013; 1830(12): 5435-5443.

37. Zeitlinger MA, Derendorf H, Mouton JW, Cars O, Craig WA, Andes D, Theuretzbacher U, Protein binding: do we ever learn?. Antimicrob Agents Chemother., 2011; 55(7): 3067-3074.

38. Zhang F, Xue J, Shao J, Jia L, Compilation of 222 drugs' plasma protein binding data and guidance for study designs. Drug Discov Today, 2012; 17(9-10): 475-485

39. Zsila F, Subdomain IB is the third major drug binding region of human serum albumin: toward the threesites model. Mol Pharm., 2013; 10(5): 1668-1682. 